\title{
Effects of urban coarse particles inhalation on oxidative and inflammatory parameters in the mouse lung and colon
}

\author{
Cécile Vignall ${ }^{1}$, Muriel Pichavant ${ }^{2}$, Laurent Y. Alleman ${ }^{3}$, Madjid Djouina ${ }^{1}$, Florian Dingreville ${ }^{1}$, Esperanza Perdrix $^{3}$, \\ Christophe Waxin ${ }^{1}$, Adil Ouali Alami², Corinne Gower-Rousseau', Pierre Desreumaux and \\ Mathilde Body-Malapel ${ }^{1 *}$ (D)
}

\begin{abstract}
Background: Air pollution is a recognized aggravating factor for pulmonary diseases and has notably deleterious effects on asthma, bronchitis and pneumonia. Recent studies suggest that air pollution may also cause adverse effects in the gastrointestinal tract. Accumulating experimental evidence shows that immune responses in the pulmonary and intestinal mucosae are closely interrelated, and that gut-lung crosstalk controls pathophysiological processes such as responses to cigarette smoke and influenza virus infection. Our first aim was to collect urban coarse particulate matter (PM) and to characterize them for elemental content, gastric bioaccessibility, and oxidative potential; our second aim was to determine the short-term effects of urban coarse PM inhalation on pulmonary and colonic mucosae in mice, and to test the hypothesis that the well-known antioxidant N-acetyl-L-cysteine (NAC) reverses the effects of PM inhalation.

Results: The collected PM had classical features of urban particles and possessed oxidative potential partly attributable to their metal fraction. Bioaccessibility study confirmed the high solubility of some metals at the gastric level. Male mice were exposed to urban coarse PM in a ventilated inhalation chamber for 15 days at a concentration relevant to episodic elevation peak of air pollution. Coarse PM inhalation induced systemic oxidative stress, recruited immune cells to the lung, and increased cytokine levels in the lung and colon. Concomitant oral administration of NAC reversed all the observed effects relative to the inhalation of coarse PM.

Conclusions: Coarse PM-induced low-grade inflammation in the lung and colon is mediated by oxidative stress and deserves more investigation as potentiating factor for inflammatory diseases.
\end{abstract}

Keywords: Particulate matter, Coarse PM, Oxidative stress, Inflammation, Gut-lung axis, N-acetyl-L-cysteine

\section{Background}

Episodic increases in ambient air contaminant levels have been demonstrated to modulate the pathogenesis of an increasing number of chronic diseases, from asthma to cancer and stroke [1]. Exposure to ambient air pollution, especially to particulate matter (PM), is a major risk factor for pulmonary diseases such as asthma, chronic bronchitis, and pneumonia [2]. Numerous epidemiological studies indicate that long- and short-term

\footnotetext{
* Correspondence: mathilde.body@univ-lille2.fr

${ }^{1}$ Inserm, CHU Lille, U995-LIRIC-Lille Inflammation Research International

Center, Univ. Lille, F-59000 Lille, France

Full list of author information is available at the end of the article
}

exposure to coarse PM is associated with adverse health effects on the human respiratory system [3].

Although research on airborne pollutants has focused mostly on cardiovascular and respiratory effects, emerging epidemiological and experimental evidence suggests that air pollutants can also cause adverse effects on the gastrointestinal tract. Recent epidemiological studies have reported that exposure to air pollution may be associated with various gastrointestinal diseases including inflammatory bowel diseases $[4,5]$, appendicitis [6], irritable bowel syndrome [7], and enteric infections in children [8]. Notably, a correlation has been reported between ambient air 
pollution and hospitalizations for inflammatory bowel diseases in Wisconsin [9].

To date, only one study has assessed the effects of PM inhalation on the gastrointestinal tract in an animal model [10]. Li et al. reported that in $\mathrm{Ldlr}^{-/-}$mice, inhalation of ultrafine PM led to shortened villus length, which was accompanied by prominent macrophage and neutrophil infiltration into the ileum. Ultrafine PM exposure also increased the concentrations of intestinal free oxidative fatty acids and lysophosphatidic acids. This study was the first to report that inhaled particles can trigger a deleterious effect at the intestinal level, which justifies the value of exploring this topic further.

Investigations of the mechanisms responsible for air pollution exposure-induced toxicity are challenging because of the complexity of air pollutants. Reactive gases such as ozone, nitrogen oxides, carbon monoxide, sulfur dioxide, volatile organic compounds and PM of varying size are part of the air pollutant mixture. The physicochemical characteristics of this complex matrix of gases and PM are also highly variable depending on the generation mode and sources (e.g., point industrial sources, automotive combustion, natural processes such as wildfires and volcanic eruptions, and atmospheric conditions) [11]. Air particles are known sinks for various organics molecules and a number of inorganic chemicals including physiologically active transition metals.

Our study focused on coarse PM, which has an aerodynamic diameter between 2.5 and $10 \mu \mathrm{m}$. It therefore includes an extra-thoracic particulate fraction (particles from 5 to $10 \mu \mathrm{m}$ in size) and a thoracic particulate fraction (particles from 2.5 to $5 \mu \mathrm{m}$ in size) [12]. The particulate fraction deposited into the extra-thoracic region becomes trapped in the nasal cavity, mouth, and pharynx. The vast majority of particules deposited in the extrathoracic region are removed via a combination of nose-blowing, sneezing, and mucociliary transport to the gastrointestinal tract [13]. Ingestion is therefore the dominant exposure pathway to particles deposited in the extra-thoracic region. Meanwhile, the thoracic particulate fraction deposits in the tracheobronchial region. This region consists of trachea, bronchi and terminal bronchioles. These particles, trapped in the mucus produced by the bronchial epithelial cells are typically cleared by mucociliary transport into the throat, and then expectored or swallowed $[14,15]$. Moreover, for both fractions, soluble particles can be absorbed directly via the airway epithelium and cleared into the blood or lymphatic system [13, 16]. Therefore, coarse PM appears to be a relevant PM fraction to study, because it comes into direct contact with the digestive tract and has several input pathways allowing it to affect both the pulmonary and intestinal mucosae.
The first objective of this study was to characterize metal content of urban coarse PM collected in the French city of Douai, hereafter called coarse $\mathrm{PM}^{\mathrm{D}}\left(\mathrm{cPM}^{\mathrm{D}}\right)$ and to assess its gastric metal bioaccessibility. Because oxidative stress is a major mechanism of PM toxicity, the oxidative potential of $\mathrm{CPM}^{\mathrm{D}}$ was quantified. The second aim was to assess the effects of inhalation of $\mathrm{CPM}^{\mathrm{D}}$ at a concentration relevant to episodic elevation peak of air pollution in mice. The third aim was to evaluate the effect of the administration of a well-known antioxidant, the N-acetyl-L-cysteine (NAC), on the effects of $\mathrm{cPM}^{\mathrm{D}}$ inhalation in mice.

\section{Methods}

\section{Sample collection}

Aerosol samples were collected with a High-Vol $\left(35 \mathrm{~m}^{3} / \mathrm{h}\right)$ six- stages $(10.2,4.2,2.1,1.4,0.73,0.41 \mu \mathrm{m})$ cascade impactor (Tisch Environmental Inc.). Particles were collected during the warm season from July 13 to October 9, 2013, in Douai, a small city in a densely urbanized region in the north of France, located about $100 \mathrm{~km}$ from the English Channel coast (Additional file 1: Figure S1). Daily meteorological data during the sampling period were retrieved from the nearest weather station of the French meteorological service Météo-France, located $20 \mathrm{~km}$ north of the sampling site at the airport of Lille-Lesquin. PM was collected onto each impactor plate covered with adhesive Teflon stripes, which allowed the particles to be easily swiped with a Teflon tip, and then transferred directly into acid-cleaned sterile tubes, weighed, homogenized, and kept at $4{ }^{\circ} \mathrm{C}$ until later sampling for chemical and biological assays. The particle fraction size of the $\mathrm{CPM}^{\mathrm{D}}$ used in this study was between 2.1 and $10.2 \mu \mathrm{m}$.

\section{Total metal concentration}

Particulate trace element mineralization and analysis were performed in triplicate, following a previously published method [17]. About $3 \mathrm{mg}$ of $\mathrm{CPM}^{\mathrm{D}}$ was acid digested in a microwave oven (Milestone ETHOS) at $220{ }^{\circ} \mathrm{C}$. Digests were diluted to $50 \mathrm{~mL}$ with ultrapure water and analyzed by inductively coupled plasma mass spectrometry (ICPMS) (NeXion 300XX, PerkinElmer) for trace elements (As, Ba, Bi, Cd, Ce, Co, Cr, Cs, Cu, Hg, La, Li, Mn, Mo, $\mathrm{Ni}, \mathrm{Pb}, \mathrm{Rb}, \mathrm{Sb}, \mathrm{Sc}, \mathrm{Se}, \mathrm{Sn}, \mathrm{Sr}, \mathrm{Th}, \mathrm{Ti}, \mathrm{Tl}, \mathrm{U}, \mathrm{V}, \mathrm{Zn}$ ) and major elements ( $\mathrm{Al}, \mathrm{Ca}, \mathrm{Fe}, \mathrm{K}, \mathrm{Mg}, \mathrm{Na})$. An internal mixed standard $(69 \mathrm{Ga}, 103 \mathrm{Rh})$ was added $(1 \mu \mathrm{g} / \mathrm{L})$ to all analyzed solutions to correct the drift of the ICP-MS signal. Reagent blanks, quality controls and standard reference materials (NIST 1648a and ERM CZ-120) were also analyzed repeatedly to validate the entire analytical procedure, as previously described [18]. The total metal concentration is expressed in micrograms of metal per gram of $\mathrm{cPM}^{\mathrm{D}}$. 


\section{Metals bioaccessibility}

Gastric bioaccessible fractions of $\mathrm{cPM}^{\mathrm{D}}$ were characterized after in vitro extraction using a synthetic gastric juice (SGJ), according to the previously described procedures [19]. The gastric extractions were performed using three aliquots of $1-5 \mathrm{mg}$ of $\mathrm{CPM}^{\mathrm{D}}$ by agitating the PM suspensions for $2 \mathrm{~h}$ at $37^{\circ} \mathrm{C}$ in accordance with the estimated physiological residence time. The separation of the particles from the synthetic fluid was performed by centrifugation for $10 \mathrm{~min}$ at $14,600 \mathrm{rpm}$ at $6{ }^{\circ} \mathrm{C}$. The supernatant was analyzed after a $\mathrm{HNO}_{3}$ digestion on a hot plate, evaporation to dryness, and dilution to $10 \mathrm{~mL}$ $\left(1 \% \mathrm{HNO}_{3}\right)$. The results are expressed in micrograms of solubilized metal in the supernatant per gram of $\mathrm{CPM}^{\mathrm{D}}$. To check the consistency of the measured concentrations, the residual fraction was acid digested in a microwave oven at $220^{\circ} \mathrm{C}$ according to the method of Alleman et al. [17]. Elemental analyses were performed in triplicate. Trace and major elements were validated through repeated analysis of reagent blanks, quality controls and standard reference materials (NIST 1648a and 2584). The bioaccessible fractions are presented as the ratio (expressed as a percentage) of metal concentration measured in the gastric leaching solutions to the total metal concentration.

\section{Oxidative potential of $\mathrm{CPM}^{\mathrm{D}}$ measured in ascorbic acid} (AA) depletion assays

Oxidative potential is defined as a measure of the capacity of PM to oxidize target molecules, here AA, by generating reactive oxygen species in an acellular assay [20]. The AA depletion assay was performed under physiological conditions: at $37{ }^{\circ} \mathrm{C}$ and $\mathrm{pH} 7.4$ in potassium Phosphatebuffered saline (PBS) at $10^{-2} \mathrm{~mol} / \mathrm{L}$, containing $30 \%$ $\mathrm{KH}_{2} \mathrm{PO}_{4}$ and $70 \% \mathrm{~K}_{2} \mathrm{HPO}_{4}$ on a molar basis, that had been pretreated with Chelex resin to remove all potential metallic contaminants. Ten milligrams of $\mathrm{CPM}^{\mathrm{D}}$ was solubilized in $300 \mathrm{~mL}$ of PBS $10^{-2} \mathrm{~mol} / \mathrm{L}$ in an ultrasonic bath for $30 \mathrm{~min}$ and then agitated at $37^{\circ} \mathrm{C}$ for $24 \mathrm{~h}$. The $\mathrm{CPM}^{\mathrm{D}}$ suspension was prefiltered through a $0.45 \mu \mathrm{m}$ syringe filter and divided into three $\mathrm{cPM}^{\mathrm{D}}$ extracts of $100 \mathrm{~mL}$ each. Next, $0.5 \mathrm{~mL}$ of AA at $4.10^{-2} \mathrm{~mol} / \mathrm{L}$ in PBS was added to each $\mathrm{CPM}^{\mathrm{D}}$ extract and the sample was mixed. The absorbance was measured at $265 \mathrm{~nm}$ for different times up to $1 \mathrm{~h}$ for both the $\mathrm{cPM}^{\mathrm{D}}$ extract solution test and the blank samples without $\mathrm{cPM}^{\mathrm{D}}$. The molar concentration of AA was then calculated from the absorbance at $265 \mathrm{~nm}$ using a preestablished calibration curve. A faster AA depletion rate in the presence of $\mathrm{CPM}^{\mathrm{D}}$ extract compared with the blank indicates that $\mathrm{CPM}^{\mathrm{D}}$ promotes the oxidation of AA. A similar assay using $10 \mathrm{mg}$ of $\mathrm{CPM}^{\mathrm{D}}$ in $300 \mathrm{~mL}$ of PBS $10^{-2} \mathrm{~mol} / \mathrm{L}$ was performed in the presence of $87.5 \mathrm{mg}$ of EDTA, a transition metal chelating agent, before introducing the AA reactant to examine the effect of metal redox activity on AA depletion (Zielinski et al., 1999). All experiments were performed in triplicate. Oxidative potential is expressed as the maximum AA depletion rate in micromoles per liter per minute (i.e., the depletion rate calculated during the first hour) calculated after subtracting the blank for a solid-to-liquid ratio of $10 \mathrm{mg}$-to- $300 \mathrm{~mL}$.

\section{Animals}

The animal treatment protocol was approved by the regional bioethics committee (committee no.75; authorization no.CEEA2016072517274040) and all of the animals received human care in accordance with the Guide for the Care and the Use of Laboratory Animals (National Research Council (US) Committee 2011).

Male C57BL/6 mice (aged 7 weeks) were purchased from Janvier Labs and housed under standard conventional conditions. The room relative humidity was $55 \%$ and the temperature was $21{ }^{\circ} \mathrm{C}$. Mice were randomly divided into the different exposure groups ( $n=10$ /group), as described in Scheme 1 and Fig. 4a.

\section{Inhalation exposures}

For inhalation experiments, mice were placed $4 \mathrm{~h} /$ day, 5 days/week for 2 weeks and for one additional day in a ventilated whole-body inhalation chamber that allowed free movement (InExpose, Scireq ${ }^{\circ}$ ) [21]. Nebulization was achieved using an Aeroneb Lab ${ }^{\mathrm{Tm}}$ ultrasonic nebulizer directly connected to a $5 \mathrm{l}$-chamber and controlled through the flexiWare software v.6 according to the following parameters: bias flow of $2 \mathrm{l} / \mathrm{min}$, nebulization rate of $0.083 \mathrm{ml} / \mathrm{min}$, which were measured and controlled throughout the experiment. The Aeroneb $\mathrm{Lab}^{\mathrm{Tm}}$ ultrasonic nebulizer produced droplets with a volume median diameter of $11 \mu \mathrm{m}$ characterized by laser diffraction using the Spraytec system from Malvern Instruments. Mice were exposed to a solution of $40 \mu \mathrm{g} \mathrm{cPM} / \mathrm{ml}$ or to the soluble or insoluble fractions of $\mathrm{CPM}^{\mathrm{D}}$. The dose concentration of the aerosol achieved with these conditions was $1.66 \mu \mathrm{g} / \mathrm{L}$. Control mice were exposed to sterile water under the same conditions. $\mathrm{CPM}^{\mathrm{D}}$ suspension was fractionated into soluble and insoluble fractions by centrifugation for $5 \mathrm{~min}$ at $13000 \mathrm{~g}$ as previously described [22, 23]. Soluble and insoluble fractions were diluted in the same volume of sterile water as the total fraction.

\section{$\mathrm{N}$-acetyl-L-cysteine (NAC) administration}

Mice were administrated NAC (Sigma-Aldrich) in drinking water $(15 \mu \mathrm{g} / \mathrm{kg} /$ day $)$, from the beginning of the PM exposure until the day of sacrifice as described in Scheme 1. 

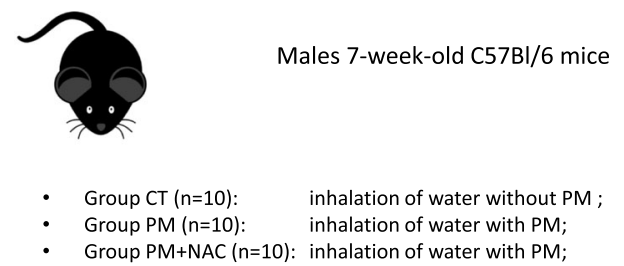

drinking water without NAC drinking water without NAC drinking water with NAC drinking water with NAC

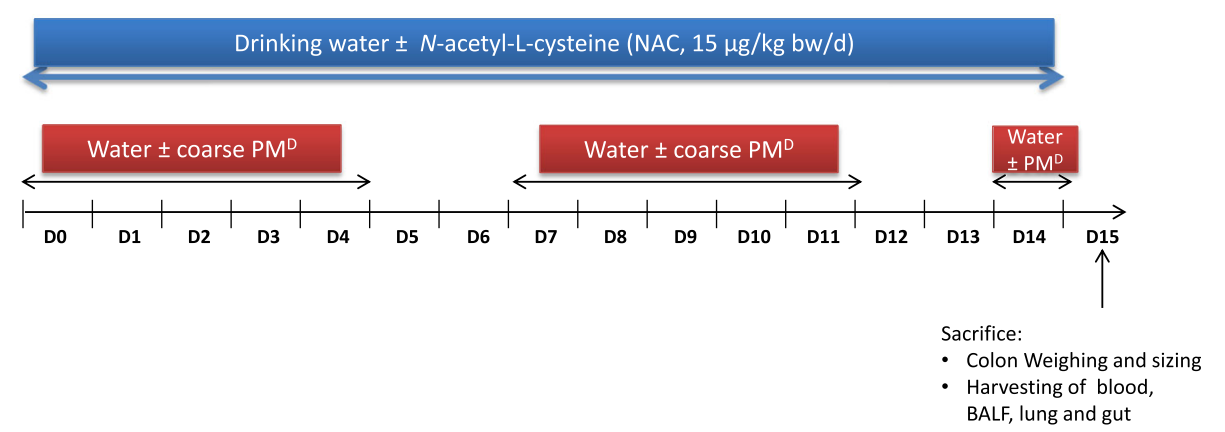

Scheme 1 Experimental design of the mouse model

\section{Biological samples}

Mice were euthanized the morning following the final exposure day. The colon was dissected and measured. Then, the colon was emptied by pushing the stool outwards using a dissecting forceps, and weighed. Bronchoalveolar lavage fluid (BALF) and samples of the lungs, colon, and blood were collected and kept on ice for FACS analysis or immediately frozen at $-80{ }^{\circ} \mathrm{C}$.

\section{Flow cytometry}

Cells harvested from BALF or extracted from lung tissue were washed in PBS and incubated with antibodies (BD, Franklin Lakes, NJ, USA) for $30 \mathrm{~min}$ in PBS and then washed twice and suspended in PBS with $2 \%$ fetal calf serum. The antibodies used were: fluorescein isothiocyanate (FITC)-conjugated anti-I-A[b]; phycoerythrin (PE)-conjugated anti-F4/80; peridinin chlorophyll protein complex (PerCP)/Cy5-conjugated anti-CD103; $\mathrm{PE} / \mathrm{Cy} 7$-conjugated anti-CD11c; allophycocyanin (APC)conjugated anti-CCR2; Alexa 700-conjugated anti-CD86; APC-H7-conjugated anti-Ly6G; V450-conjugated antiCD11b; V500-conjugated anti-CD45; BV605-conjugated anti-Ly6C; FITC-conjugated anti-CD5; PE-conjugated anti-CD1d tetramer; PerCP/Cy5-conjugated anti-NK1.1; APC-conjugated anti-CD25; Alexa 700-conjugated antiCD69; APC-H7-conjugated anti-CD4; V450-conjugated anti-T-cell receptor- $\beta$; V500-conjugated anti-CD8, and BV605-conjugated CD45. Cells were analyzed on an LSR Fortessa cell analyzer (BD). The generated data were analyzed using FlowJo 8.7 (TreeStar, Stanford, CA, USA).

\section{Gene expression in tissues}

Total mRNA from lung and colon tissues was extracted using a Nucleospin RNA II kit (Macherey Nagel). Reverse transcription was performed using a High Capacity cDNA Archive Kit and quantitative polymerase chain reaction (PCR) with SYBR Green (Life Technologies). The primer sequences were designed using Primer Express 3 (Life Technologies) and are available upon request. Melting curve analyses were performed for each sample and gene to confirm the specificity of the amplification. Because the exposure to PM did not cause any significant alterations in Polr $2 a$ mRNA expression, the relative expression of each gene of interest was normalized to the relative expression of this gene. The quantification of the target gene expression was based on the comparative cycle threshold $(\mathrm{Ct})$ value. The fold changes in the target genes were analyzed by the $2^{-\Delta \Delta C t}$ method [24].

\section{Serum malondialdehyde (MDA) analysis}

Serum samples $(50 \mu \mathrm{L})$ were incubated with acetic acid and SDS at $95{ }^{\circ} \mathrm{C}$ for $1 \mathrm{~h}$, followed by centrifugation at $800 \mathrm{~g}$ for $10 \mathrm{~min}$. Supernatants were transferred to a 96-well plate and the absorbance was measured at $\lambda_{\mathrm{ex}}=$ 532 and $\lambda_{\mathrm{em}}=553 \mathrm{~nm}$. 1,1,3,3-Tetramethoxypropane (Sigma-Aldrich) was used as a standard. Protein concentration in samples was determined using a $\mathrm{DC}^{\mathrm{rm}}$ protein assay (Bio-Rad Laboratories). Serum MDA concentration was corrected by the sample protein concentration and is expressed as nanomoles per milliliter of serum. 


\section{Myeloperoxidase activity assay}

Neutrophil influx into colon was analyzed by measuring the enzymatic activity of myeloperoxidase (MPO). Mice colons were homogenized in $0.5 \%$ hexadecyltrimethylammonium bromide (Sigma-Aldrich) in $50 \mathrm{mM}$ PBS, freeze-thawed three times, and centrifuged. MPO was analyzed in the clear supernatant by adding $1 \mathrm{mg} / \mathrm{mL}$ of dianisidine dihydrochloride (Sigma-Aldrich) and $5.10^{-4} \%$ hydrogen peroxide $\left(\mathrm{H}_{2} \mathrm{O}_{2}\right)$, and the change in optical density was measured at $450 \mathrm{~nm}$. Human neutrophil MPO (Sigma-Aldrich) was used as a standard. One unit of MPO activity was defined as the amount that degraded $1 \mu \mathrm{mol}$ of peroxide per min at $25{ }^{\circ} \mathrm{C}$. Readings from tissue samples were normalized to total protein content as detected in the $\mathrm{DC}^{\mathrm{mm}}$ protein assay (Bio-Rad).

\section{Statistical analysis}

Results are expressed as mean \pm SEM. The statistical significance of differences between experimental groups was calculated using the Mann-Whitney U test (GraphPad, San Diego, CA).

\section{Results}

\section{Characteristics of $\mathrm{CPM}^{\mathrm{D}}$}

The meteorological conditions during the sampling period were typical for summertime under the oceanic climate of the northwestern European coast. The daily averages were a temperature of $17.7{ }^{\circ} \mathrm{C}$ (Additional file 1: Figure S2A), $71 \%$ relative humidity (Additional file 1: Figure S2B), $1017 \mathrm{hPa}$ atmospheric pressure and cumulated rain of $172 \mathrm{~mm}$ over the whole period (Additional file 1: Figure S2C). These relatively high pressures and sparse rainfall conditions were observed throughout the period, and a continuing decrease in temperature and increase in relative humidity were recorded from summer to mid-autumn. The average wind speed was $3.3 \mathrm{~m} / \mathrm{s}$ (Additional file 1: Figure S2D) and winds came mostly (39\%) from the west sector (marine air masses from the English Channel and Atlantic Ocean) and secondarily (28\%) from the north sector (more continental air masses toward the regional Scarpe-Escaut natural park and the south of Belgium (Additional file 1: Figure S2E).

The concentrations of elements in $\mathrm{CPM}^{\mathrm{D}}$ varied from 1 to $57,312 \mu \mathrm{g} / \mathrm{g}$ in the following order: $\mathrm{U}<\mathrm{Tl}<\mathrm{Cs}<\mathrm{Th}<$ $\mathrm{Sc}<\mathrm{Hg}<\mathrm{Bi}<\mathrm{Se}<\mathrm{La}<\mathrm{Li}<\mathrm{Cd}<\mathrm{Co}<\mathrm{As}<\mathrm{Ce}<\mathrm{Mo}<\mathrm{Rb}<$ $\mathrm{V}<\mathrm{Ni}<\mathrm{Sb}<\mathrm{Sn}<\mathrm{Cr}<\mathrm{Sr}<\mathrm{Pb}<\mathrm{Ba}<\mathrm{Cu}<\mathrm{Mn}<\mathrm{Ti}<\mathrm{Zn}$ for trace elements and $\mathrm{Mg}<\mathrm{K}<\mathrm{Al}<\mathrm{Fe}<\mathrm{Na}<\mathrm{Ca}$ for major elements (Fig. 1a). Enrichment factors relative to the upper continental crust with Th as the reference element [25] were applied to assess the anthropogenic influence on $\mathrm{CPM}^{\mathrm{D}}$ content (Fig. 1b). Enrichment factors $>10$ were observed for $\mathrm{As}, \mathrm{Mo}, \mathrm{Sn}, \mathrm{Pb}, \mathrm{Cu}, \mathrm{Bi}, \mathrm{Zn}, \mathrm{Cd}$, and $\mathrm{Sb}$. All of these elements are commonly associated with traffic nonexhaust emissions (i.e., brakes and tire wear), particularly $\mathrm{Cu}$, which is predominant in coarse PM in Europe [26], and $\mathrm{Sb}$, which showed the highest enrichment factor, and confirmed the urban typology of the sampling site. Cd, $\mathrm{Zn}, \mathrm{Bi}$, and $\mathrm{Pb}$ are known tracers of nonferrous smelting [27-29] and their enrichment may indicate the influence of a nearby $\mathrm{Zn}$ smelter located $3 \mathrm{~km}$ north of our sampling site. To characterize $\mathrm{cPM}^{\mathrm{D}}$ better, we sought to assess their features in relation to other urban coarse PM. For this purpose, the elemental concentrations in $\mathrm{CPM}^{\mathrm{D}}$ were compared with those measured in other European cities: an urban site in Helsinki, Finland [30] and a traffic site in Budapest, Hungary [31] (Additional file 1: Figure S3). Globally, the elemental concentrations were very similar, except for the highest levels of $\mathrm{Cd}, \mathrm{Zn}$ and $\mathrm{Bi}$ in Douai, in accordance with a significant influence of the nearby $\mathrm{Zn}$ smelter.

\section{Gastric bioaccessibility of $\mathrm{CPM}^{\mathrm{D}}$}

Simulation of solubilization pathways was performed using the SGF to approximate gastric conditions (Fig. 1c). Metals showing the higher gastric bioaccessibility were $\mathrm{Pb}>\mathrm{Sb}>\mathrm{Cd}>\mathrm{Co}>\mathrm{Sr}$, with values ranging from $90 \%$ for $\mathrm{Pb}$ to $70 \%$ for $\mathrm{Sr}$. The lowest gastric bioaccessibility were observed for $\mathrm{Cr}(9 \%)$ and $\mathrm{Fe}(11 \%)$.

\section{Oxidative potential of $\mathrm{CPM}^{\mathrm{D}}$}

The oxidative potential of $\mathrm{CPM}^{\mathrm{D}}$ was assessed using an AA depletion assay (Fig. 1d); AA is an antioxidant naturally present in the human body. The rates of AA depletion measured showed the effective oxidative potential of $\mathrm{CPM}^{\mathrm{D}}$. To examine the effects of metal redox activity on AA depletion, the same experiment was performed in the presence of EDTA, a transition metal chelating agent. In the presence of EDTA, AA depletion was significantly lower $(-42 \%)$ although not totally depleted, which indicates a role of metals in the oxidative potential of $\mathrm{CPM}^{\mathrm{D}}$.

\section{Effects of $\mathrm{CPM}^{\mathrm{D}}$ inhalation on oxidative stress and inflammation in mice}

We then exposed mice to this $\mathrm{CPM}^{\mathrm{D}}$ by inhalation in a whole body inhalation chamber. By this physiological way of exposure, as in real-life, coarse PM is expected to deposit primarily in the upper respiratory tract, and then to be transported from the conducting airways to the gastrointestinal tract by mucociliary clearance [12, 32]. We first aimed to assess the effects of an environmentally relevant episodic increase in ambient PM exposure on pulmonary and intestinal mucosal tissues. Following 14 days of exposure to inhaled $\mathrm{cPM}^{\mathrm{D}}$, serum MDA concentration was significantly higher in the PM mice compared with CT mice that inhaled only water. This finding reflects the appearance of systemic oxidative stress (Fig. 2a). More cells were obtained in BALF from PM mice 


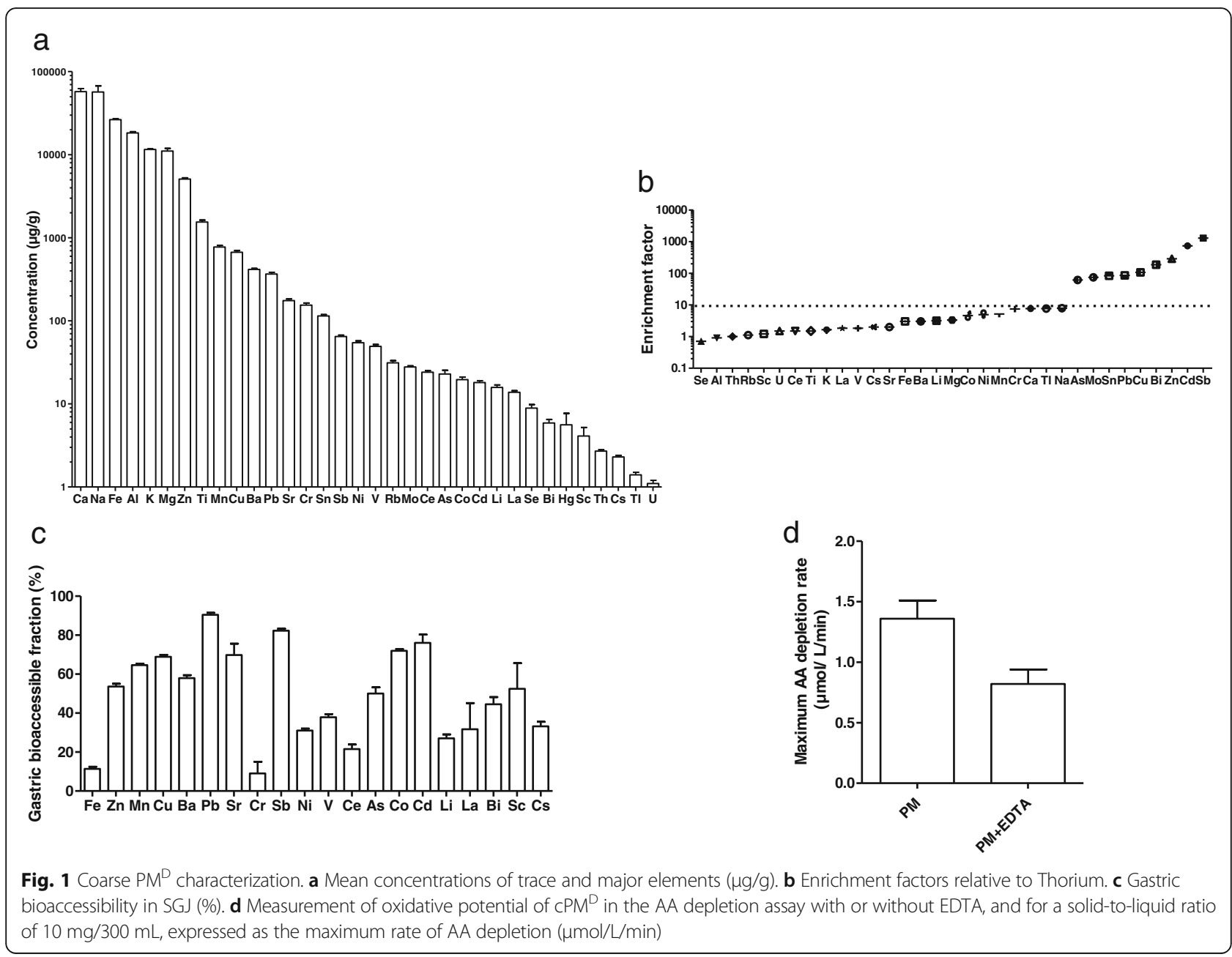

compared with CT mice (Fig. 2b). The numbers of neutrophils and alveolar macrophages in the lung did not differ significantly between PM and CT mice (Fig. 2c). By contrast, more conventional $\mathrm{T}$ cells and invariant natural killer (iNKT) cells were observed in the lung of PM mice, and these increased cell numbers were associated with higher Tnfo, Il5, Il22, and Il10 mRNA levels (Fig. 2d). At the intestinal level, the colon weight size ratio did not differ between PM and CT mice (Fig. 2e). A trend toward an increase in MPO activity was observed in the colons of PM mice (Fig. 2f). The gene expression levels of markers of neutrophils (Csf $3 r$ ), macrophages (Cd68), conventional T cells $(C d 247)$, and iNKT cells (Vo14) did not differ between PM and CT mice (Fig. 2g). By contrast, significantly greater expression of Tnfo, Ifny, Illo and Cxcl10, and lower expression of $I l 5$ were found in the colons of PM mice compared with CT mice (Fig. 2h). Together, these results suggest that $\mathrm{CPM}^{\mathrm{D}}$ inhalation led to low-grade inflammation in both the lungs and gut.

\section{Effects of NAC administration on $\mathrm{CPM}^{\mathrm{D}}$-induced deleterious effects}

Oral administration of NAC has been shown to protect against oxidative stress in the lung [33, 34]. We evaluated the consequences of NAC administration on the previously observed PM-induced effects. NAC was added to drinking water of mice that inhaled PM $(\mathrm{PM}+\mathrm{NAC}$ mice). A group of mice that inhaled PM and did not receive NAC in drinking water was also included (PM mice). Serum MDA concentration was lower in PM + NAC mice than in PM mice (Fig. 3a). Fewer cells were found in BALF from PM + NAC mice than in that from PM mice (Fig. 3b). In the lungs, less iNKT recruitment (Fig. 3c) and lower Ifny, Il5 and Cxcl10 expression levels were observed (Fig. 3d). The mRNA levels of several oxidative stress markers such as Nos2, COX2, Sod2, Cat, and Hmox1 were markedly lower in the lungs of PM + NAC mice compared with those from PM mice (Fig. 3e). The colons of PM + NAC mice showed lower MPO activity (Fig. 3f) and reduced Tnfa, Ifn $\gamma$ and Cxcl10 mRNA expression compared 


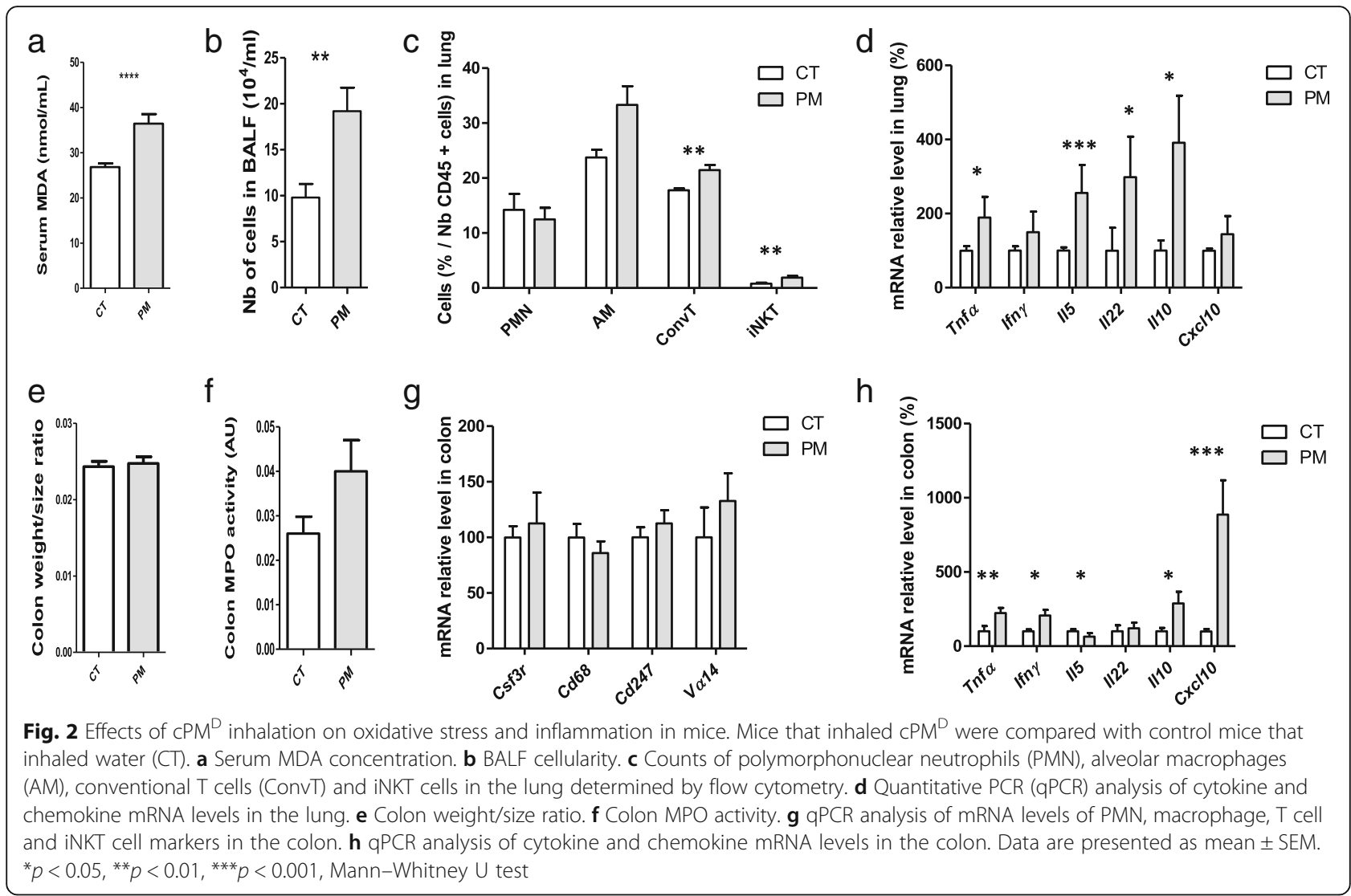

with those from PM mice (Fig. 3g). Taken together, these data show that NAC administration reversed the deleterious effects induced by PM inhalation. NAC did not alter the basal condition because NAC treatment did not modify inflammatory and oxidative stress parameters in serum, lung, or colon of CT mice that inhaled water (Additional file 1: Figure S4).

\section{Involvement of water-soluble and insoluble fractions on $\mathrm{CPM}^{\mathrm{D}}$-induced low-grade inflammation}

To assess if the solubilization of PM in water during nebulization is involved in the observed low-grade inflammation, an experiment was performed including in addition to the 2 previously described groups [mice exposed to water (CT group), and mice exposed to $\mathrm{CPM}^{\mathrm{D}}$ (total fraction, FT group)], a group exposed to the soluble fraction of $\mathrm{cPM}^{\mathrm{D}}$ (Soluble Fraction, SF group) and a group exposed to the insoluble fraction of $\mathrm{CPM}^{\mathrm{D}}$ (Insoluble Fraction, IF group) (Fig. 4a). The increased number of cells in BALF in TF-exposed mice compared to CT mice was found also in IF-exposed mice, and not in SFexposed mice (Fig. 4b). Similarly, the enhancement of iNKT cells in lungs of TF-exposed mice compared to CT mice was also found in IF-exposed mice, and not in SF-exposed mice (Fig. 4c). In the colon, an unexpected decrease of $\operatorname{Tnf} \alpha$ levels was quantified in IF-exposed mice compared to CT mice (Fig. 4d). Most interestingly, no increase of Tnf $\alpha$ and $C x c l 2$ mRNA levels was detected in the colons of SF-exposed mice, while the transcription of both genes was increased in TF-exposed mice. Taken together, these results show that the water-soluble fraction of $\mathrm{CPM}^{\mathrm{D}}$ is not sufficient to induce the low-grade inflammation associated to $\mathrm{CPM}^{\mathrm{D}}$ inhalation.

\section{Discussion}

The $\mathrm{CPM}^{\mathrm{D}}$ used in this study comprised urban particles collected over 4 months of the warm season in northern France, and ranged in size from 2.1 to $10,2 \mu \mathrm{m}$. Fe, Cu, and $\mathrm{Zn}$ were among the most concentrated metals quantified in $\mathrm{CPM}^{\mathrm{D}}$, and their high concentrations are of concern because of their pro-oxidative potential [35]. The most enriched element was $\mathrm{Sb}$, which is consistent with the main traffic-related origin of $\mathrm{CPM}^{\mathrm{D}}$. Another metal of concern is $\mathrm{Pb}$, which is highly toxic and is enriched by 86 times in $\mathrm{CPM}^{\mathrm{D}}[36,37]$. Both $\mathrm{Sb}$ and $\mathrm{Pb}$ concentrations were similar to those reported for other urban areas [30, 38, 39]. The strong enrichment for $\mathrm{Cd}$ and As in $\mathrm{cPM}^{\mathrm{D}}$ compared with the upper crust is likely to contribute to their negative health impact. $\mathrm{Cd}$ exposure is known to induce pulmonary damage such as emphysema and lung cancer $[40,41]$ and to cause intestinal inflammation in mice [42]. Similarly, As exposure has 


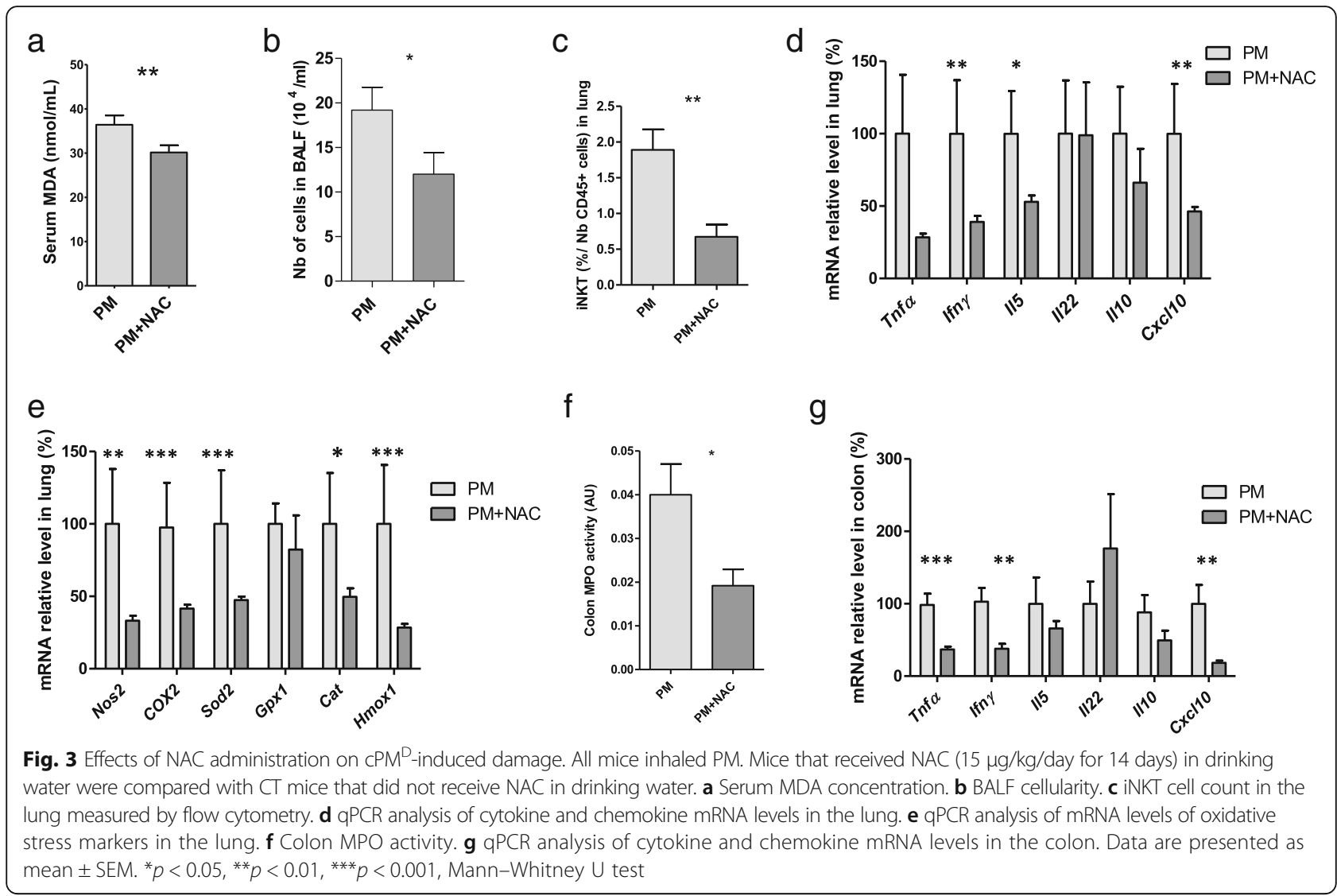

been repeatedly associated with lung carcinogenesis [43] and has been shown to perturb the gut microbiome in mice [44].

Furthermore, $\mathrm{Pb}, \mathrm{Sr}, \mathrm{Sb}, \mathrm{Co}$ and $\mathrm{Cd}$ presented both high concentration in $\mathrm{CPM}^{\mathrm{D}}$ and high gastric bioaccessibility. A substantial proportion of these elements is therefore likely to be found in the bloodstream during air pollution peak in urban areas. The diffusion of these metals in the bloodstream could lead to both directly cytotoxic effects on circulatory monocytes [45], but also to indirectly aggravating effects on inflammation in peripheral tissues: notably, lead and cadmium levels in PM have been found negatively associated with miR-146a expression in blood leukocytes RNA from foundry workers [46]. Mir-146a is involved in limiting inflammatory responses triggered through the innate immune system [47]. Moreover, miR-146a-mediated NOD2-SHH signaling regulates gut inflammation in murine model of inflammatory bowel diseases [48].

The main objective of the current study was to assess the effects of $\mathrm{cPM}^{\mathrm{D}}$ inhalation at both the pulmonary and colonic levels. Our in vivo study was conducted in conditions as close as possible to real life, and aimed to determine the effects of a realistic inhalation of coarse PM. Exposure in an inhalation chamber was preferred to oral or intratracheal administration. For their aerosolization, the $\mathrm{CPM}^{\mathrm{D}}$ were solubilized in sterile water; the impact of solubilization on the observed effects seems negligible, since the mice that inhaled the water-soluble fraction of the $\mathrm{CPM}^{\mathrm{D}}$ did not exhibit pulmonary and colon low-grade inflammation. The dosage of PM nebulized in the inhalation chamber is close to that breathed during pollution peaks by inhabitants of megacities strongly affected by particulate pollution. In urban areas, the mean daily concentration of $\mathrm{PM}$ of $\leq 10 \mu \mathrm{m}$ in diameter $\left(\mathrm{PM}_{10}\right)$ ranges from $<10 \mu \mathrm{g} / \mathrm{m}^{3}$ to $>200 \mu \mathrm{g} / \mathrm{m}^{3}$ [49]. In 2002, the US Environmental Protection Agency reported a range of maximal city PM concentrations of $26-534 \mu \mathrm{g} / \mathrm{m}^{3}$ [50]. Extreme hourly concentrations of $\mathrm{PM}_{10}$ reaching $800 \mu \mathrm{g} / \mathrm{m}^{3}$ have been measured at a traffic site in London [51]. $\mathrm{PM}_{10}$ pollution peaks at $>250 \mu \mathrm{g} / \mathrm{m}^{3}$ were measured in megacities in India, Pakistan and China in 2010 [52, 53]. Therefore, the dose used here is fairly representative of high pollution episodes in the most affected megacities worldwide.

The studies performed until now that assess the effects of coarse PM at the pulmonary level were performed using intratracheal instillation or oropharyngeal aspiration [54-57]; these two modes of coarse PM administration partially or totally excluded the physiological exposure of the mouth, nose, larynx and pharynx. They revealed in most of the cases pulmonary inflammation, which the 


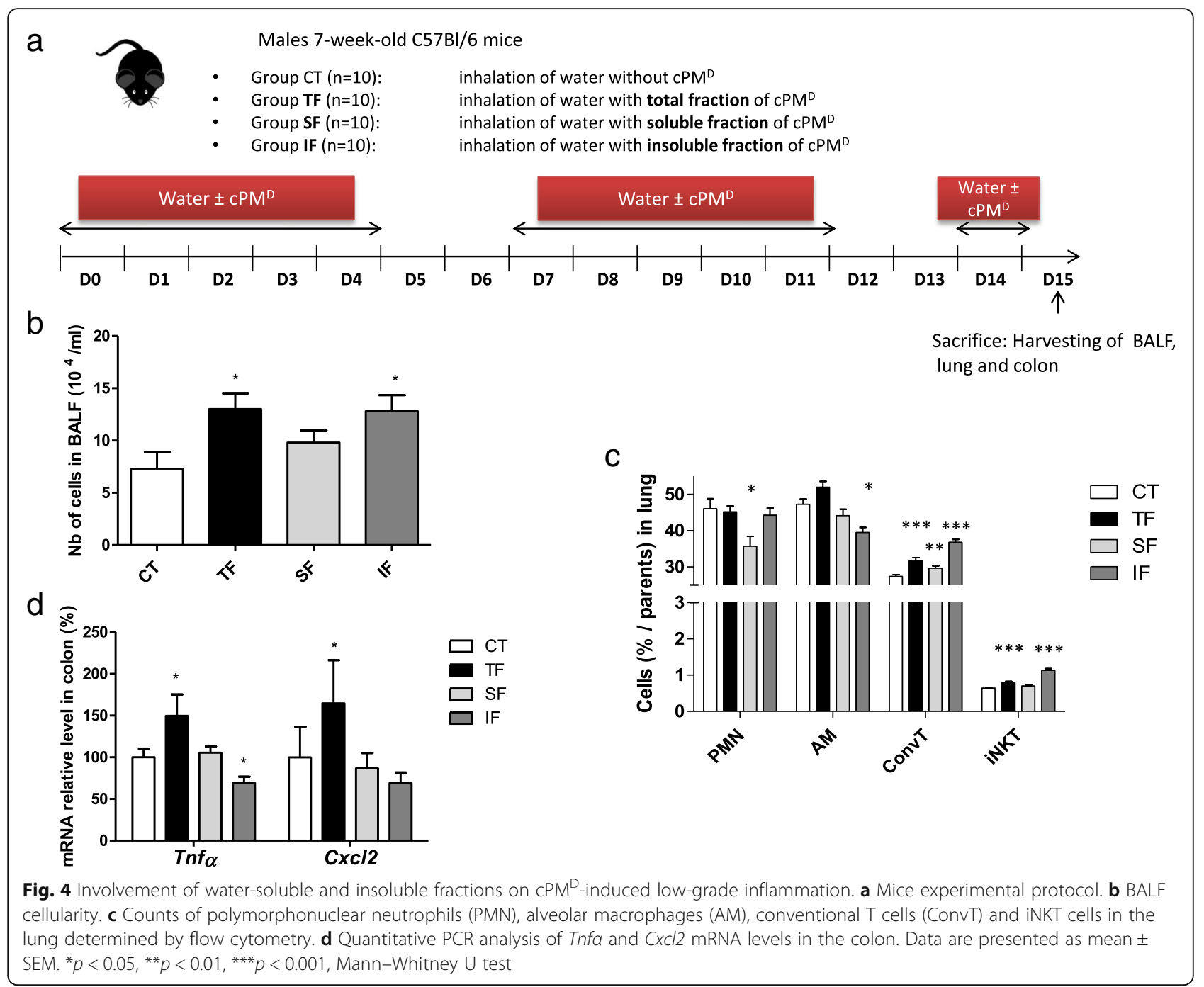

players were variable regarding the type of PM, the timing and the dose of exposure. Some consistencies can however be found with our study assessing the effects of coarse PM following inhalation. Tumor necrosis factor (TNF $\alpha$ ) produced by activated alveolar macrophages and by epithelial cells is a master cytokine of the inflammation induced by PM in the lung $[58,59]$. As for TNF $\alpha$, increased levels of interleukin 5 (IL-5), IL-10, and IL-22 are in agreement with previous studies. Overexpression of both IL-5 and IL-10 in the lung has been shown following early life exposure to combustionderived PM [58]. IL-22 upregulation may be linked to activation of the aryl hydrocarbon receptor (AHR), as reported by previous work showing the ability of urban dust PM to induce Th17 polarization and IL-22 production in an AHR-dependent manner [60]. The most pronounced effects on the recruitment of immune cells involved in pulmonary inflammation induced by $\mathrm{cPM}^{\mathrm{D}}$ seemed to involve iNKT cells. Our report is the first to show that this immune population is associated with PM exposure, although its key role has been demonstrated in the pulmonary response to ozone [61] and cigarette smoke [62].

Few studies have assessed the effects of PM inhalation at the intestinal level. As expected because of the low dose of $\mathrm{CPM}^{\mathrm{D}}$ used, we did not find evidence of colitis clinical manifestation in the PM-exposed mice, as reflected by the lack of effect on the colon weight size ratio. Accordingly, some major intestinal immune populations, namely neutrophils, macrophages, lymphocytes and iNKT cells, do not seem to be significantly affected by PM inhalation. However, the increase in colon MPO activity, which almost reached significance, as well as the strong increase in the colonic expression of Tnfo, Ifny and Cxcl10 argue in favor of a low-grade inflammation generated in colon following PM inhalation. The large production of Il10 may be indicative of a regulatory response, although the decrease in $\mathrm{Il}$ level remains unexplained. 
It is the first time that the effects of coarse PM administration on mice are studied by natural ventilation in an inhalation chamber. Nevertheless, when a high dose of coarse PM was administrated to mice by gavage during 14 days, an increase of pro-inflammatory cytokines (Il12a, Il17, and Il2) has been described [63]. Moreover, increases in colon TNF $\alpha$ and IFN $\gamma$ protein levels have also been reported following 10 and 14 weeks of oral coarse PM intoxication in mice starting from the neonatal period [64]. Taken as a whole, the experimental protocols used to explore the effects of coarse PM on the gastrointestinal tract consistently describe low-grade intestinal inflammation, but are too diverse to reveal the common immune cells or molecular pathways implicated in the colonic effects of PM. Notably, it remains to be determined whether the observed effects on the gastrointestinal tract are mediated through a topical effect of PM, which comes into direct contact with intestinal epithelium, or through a systemic mechanism.

The triggering of low-grade intestinal inflammation could contribute in part to many health issues. Low-grade intestinal inflammation is a feature of irritable bowel syndrome [65]. It could also exacerbate Inflammatory Bowel Diseases [66], and promote colon carcinogenesis [67]. Moreover, a huge body of evidence indicates that lowgrade intestinal inflammation participates in whole-body metabolism, and therefore to the metabolic syndrome that embraces cardiovascular diseases, type 2 diabetes, and non-alcoholic liver disease $[68,69]$. It has also been speculated that intestinal low-grade inflammation associated with dysbiosis may play a pathophysiological role in human brain diseases, including autism spectrum disorder, anxiety, depression, and chronic pain [66, 70]. Intestinal low-grade inflammation has also been associated with chronic obstructive pulmonary disease [71]. Because of its critical role in health, any disturbance of intestinal immune homeostasis should be considered as a serious health threat.

A prominent finding of our study is that oxidative stress was a key mechanism for PM-induced deleterious effects. The AA depletion assay showed the oxidative potential of $\mathrm{CPM}^{\mathrm{D}}$ and the involvement of metal content in this property. Consistently, PM metal chelation prevents the systemic inflammatory response induced in mice by repeated PM intratracheal instillations [72]. Quinones [73] and polycyclic aromatic hydrocarbons [74] present in PM are likely to also contribute to the oxidative potential of $\mathrm{CPM}^{\mathrm{D}}$. The increase in serum MDA concentrations that we observed in $\mathrm{CPM}^{\mathrm{D}}$-exposed mice reflects systemic oxidative stress, which is a well-known effect of PM in rats [75] and in humans [76]. NAC has been used for several years as an antioxidant agent [77-79]. In our study, NAC administration led to a normalization of pulmonary and systemic phenotypes. Our results lead us to hypothesize a similar mechanism to that demonstrated in chronic obstructive pulmonary disease induced in mice by cigarette smoke exposure [34]: that the protective effects of NAC are mediated through reduced accumulation and activation of iNKT cells. Most noticeably, NAC administration led to obvious protective effects in the colon, such as downregulation of MPO activity and complete reversal of the phenotype observed in PM-exposed mice compared with control mice, i.e., extinction of Tnfa, Ifn $\gamma$, and Illo upregulation. Because the concentration of NAC shown to induce significant improvement in colitis following oral administration $(150 \mathrm{mg} / \mathrm{kg}$ body weight (bw)/day [80] or $160 \mathrm{mg} / \mathrm{kg} \mathrm{bw} /$ day [81]) is much higher than that used in our study ( $15 \mu \mathrm{g} / \mathrm{kg}$ bw/day), these effects are not likely to be attributed to a topical effect of NAC.

NAC has been also described as a metal-chelating agent, able to increase urine gold excretion in rheumatoid arthritis patients treated with gold sodium thiomalate [82]. Moreover, intraperitoneal administration of NAC was very effective in increasing the urinary excretion of chromium and borate, but not lead, in rats intoxicated with potassium dichromate, boric acid and lead tetracetate respectively [83]. On the other hand, when NAC is administrated orally, its anti-oxidative properties are not systematically associated with chelating effects. By instance, in leadexposed mice, oral administration of NAC $(5.5 \mathrm{mmol} / \mathrm{kg})$ reduced several indices of oxidative stress in both brain and liver samples, but not tissue lead levels [84]. Similarly, NAC treatment of arsenic-exposed rats $(1 \mathrm{mmoml} / \mathrm{kg})$ did not reduce significantly blood and liver arsenic levels, but reversed the elevation of brain MDA levels observed in untreated animals exposed to arsenic [85]. Especially, if the effects observed are mediated by the bioaccessible metal fraction of PM, it can be hypothesized that the attenuating effects of NAC are partly due to its metal chelating properties, but it is unlikely that this is the major mode of action of NAC.

Taken together, our results suggest that PM inhalation induces a succession of oxidative and inflammatory reactions that involve immune populations in the blood and in the pulmonary and gastrointestinal mucosae. Our work did not allow us to determine how these populations communicate but highlight an involvement of the gut-lung axis. This concept is strengthened by several lines of evidence showing the pathophysiological relevance of the immune crosstalk between the gut and lung. For example, house dust mite aeroallergens induce inflammation in the respiratory mucosa and reduce the gut epithelial barrier integrity [86]. In allergic airway disease, gut microbiota metabolism of dietary fibers influences the severity of allergic inflammation [87]. The importance of the gut microbiota has also been reported during respiratory influenza virus infection [88] and pneumococcal pneumonia [89]. The effects of cigarette smoke on the small intestine 
and colon, as evidenced by epithelial barrier defects, inflammatory cell recruitment, and microbial shifts, have been well described [62, 90, 91]. Therefore, our data demonstrating the deleterious effects of inhaled PM on both the pulmonary and colonic mucosae constitute additional evidence for the gut-lung axis, which deserves further investigation.

\section{Conclusions}

In healthy mice, inhalation of urban coarse PM which presented with significant oxidative potential induced a lowgrade inflammation that affected both the pulmonary and colonic mucosae. The development of this low-grade inflammation was at least partly driven by an oxidative stress mechanism, as evidenced by its reversal by concomitant administration of the antioxidative compound NAC. Our results provide further demonstration of a gutlung axis, and highlight the importance of understanding the mechanisms of crosstalk between the pulmonary and colonic mucosae. Together with previous experimental and epidemiological observations, our study strongly suggests that coarse PM inhalation may trigger or accelerate the development of both pulmonary and gastrointestinal inflammatory diseases, particularly in genetically susceptible individuals.

\section{Additional file}

Additional file 1: Figure S1. Location of the sampling site. Figure S2. Meteorological conditions during the sampling period. A Temperature. B Relative humidity. C Rain. D Wind speed. E Wind direction and frequency. Figure S3. Comparison of trace element concentrations in $C P M^{D}$ collected at Douai and coarse PM collected in Helsinki, Finland [30] and Budapest, Hungary [31]. Figure S4. Effects of NAC in the basal condition. All mice inhaled sterile water. Mice that received NAC (15 $\mu \mathrm{g} / \mathrm{kg} /$ day for 14 days) in drinking water were compared with $C T$ mice that did not receive NAC in drinking water. A Serum MDA levels. B iNKT cell count measured by flow cytometry. C Quantitative PCR ( $P P C R$ ) analysis of cytokine and chemokine mRNA levels in the lung. D qPCR analysis of mRNA levels of oxidative stress markers in the lung. E MPO activity in the colon. $\mathbf{F}$ qPCR analysis of cytokine and chemokine mRNA levels in the colon. Data are presented as mean \pm SEM. ${ }^{*} p<0.05$, Mann-Whitney $U$ test. (DOCX 1064 kb)

\section{Abbreviations}

AA: Ascorbic acid; AHR: Aryl hydrocarbon receptor; AM: Alveolar macrophage; APC: Allophycocyanin; BALF: Bronchoalveolar lavage fluid; Cat: Catalase; Cd: Cluster of differentiation; ConvT: Conventional T cell; COX2: Cytochrome c oxidase subunit II; $\mathrm{CPM}^{\mathrm{D}}$ : Coarse particulate matter from Douai; Csf3r: Colony stimulating factor 3 receptor; CT: Control; Cxcl10: C-X-C motif chemokine 10; CxCl2: C-X-C motif chemokine 2; FITC: Fluorescein isothiocyanate; Gpx1: Glutathione peroxidase 1; Hmox1: heme oxygenase 1; ICP-MS: Inductively coupled plasma mass spectrometry; Ifny: Interferon gamma; II: Interleukin; iNKT: Invariant Natural Killer T cell; MDA: Malondialdehyde; MPO: Myeloperoxidase; NAC: N-acetyl-L-cysteine; Nos2: Nitric Oxide Synthase 2; PE: Phycoerythrin; PerCP: Peridinin chlorophyll protein complex; PM: Particulate matter; PMN: Polymorphonuclear neutrophil; SGJ: Synthetic gastric juice; Sod2: Superoxide dismutase 2; Tnfa: Tumor necrosis factor alpha; Va14: $V$ alpha 14

\section{Funding}

This work was supported by the Hauts-de-France Region and the Ministère de l'Enseignement Supérieur et de la Recherche (CPER Climibio), the European Fund for Regional Economic Development, and Digestscience (European Research Foundation on Intestinal Diseases and Nutrition).

\section{Availability of data and materials}

Data supporting the findings are found within the manuscript. Raw data files will be provided by the corresponding author upon request.

\section{Authors' contributions \\ $M D, F D, C W$ performed the animal exposure, acquired and analyzed the data. $C V, M P$ and MBM interpreted the results of animal experiments. LYA, EP, AOA performed the particulate matter collect and analysis, and interpreted the results of these experiments. MBM drafted the manuscript. CV and MBM shared study supervision. CG and PD participated in manuscript writing. All authors read and approved the final manuscript.}

\section{Authors' information}

Not applicable

\section{Ethics approval and consent to participate}

The animal treatment protocol was approved by the regional bioethics committee (committee no.75; authorization no.CEEA2016072517274040) and all of the animals received human care in accordance with the Guide for the Care and the Use of Laboratory Animals (National Research Council (US) Committee 2011).

\section{Consent for publication}

Not applicable

\section{Competing interests}

The authors declare they have no competing financial interests.

\section{Publisher's Note}

Springer Nature remains neutral with regard to jurisdictional claims in published maps and institutional affiliations.

\section{Author details}

'Inserm, CHU Lille, U995-LIRIC-Lille Inflammation Research International Center, Univ. Lille, F-59000 Lille, France. 'Inserm U1019, CNRS UMR 8204, Institut Pasteur de Lille- CIIL - Center for Infection and Immunity of Lille, Univ. Lille, F-59000 Lille, France. ${ }^{3}$ SAGE - Département Sciences de I'Atmosphère et Génie de l'Environnement, IMT Lille Douai, Univ. Lille, 59000 Lille, France.

Received: 27 February 2017 Accepted: 10 November 2017

Published online: 22 November 2017

References

1. Anderson JO, Thundiyil JG, Stolbach A. Clearing the air: a review of the effects of particulate matter air pollution on human health. J Med Toxicol. 2012;8:166-75.

2. Chen B, Kan H. Air pollution and population health: a global challenge. Environ Health Prev Med. 2008;13:94-101.

3. Badyda A, Gayer A, Czechowski PO, Majewski G, Dąbrowiecki P. Pulmonary function and incidence of selected respiratory diseases depending on the exposure to ambient PM10. Int J Mol Sci. 2016, 1954;17

4. Beamish LA, Osornio-Vargas AR, Wine E. Air pollution: an environmental factor contributing to intestinal disease. J. Crohns Colitis. 2011;5:279-86.

5. Kaplan G. Air pollution and the inflammatory bowel diseases. Inflamm Bowel Dis. 2011;17:1146-8.

6. Kaplan GG, Dixon E, Panaccione R, Fong A, Chen L, Szyszkowicz M, et al. Effect of ambient air pollution on the incidence of appendicitis. Can Med Assoc J. 2009;181:591-7.

7. Kaplan GG, Szyszkowicz M, Fichna J, Rowe BH, Porada E, Vincent R, et al. Non-specific abdominal pain and air pollution: a novel association. PLoS One. 2012;7:e47669.

8. Orazzo F, Nespoli L, Ito K, Tassinari D, Giardina D, Funis M, et al. Air pollution, aeroallergens, and emergency room visits for acute respiratory 
diseases and gastroenteric disorders among young children in six Italian cities. Environ Health Perspect. 2009;117:1780-5.

9. Ananthakrishnan AN, McGinley EL, Binion DG, Saeian K. Ambient air pollution correlates with hospitalizations for inflammatory bowel disease: an ecologic analysis. Inflamm Bowel Dis. 2011;17:1138-45.

10. Li R, Navab K, Hough G, Daher N, Zhang M, Mittelstein D, et al. Effect of exposure to atmospheric ultrafine particles on production of free fatty acids and lipid metabolites in the mouse small intestine. Environ Health Perspect. 2015;123:34-41.

11. Kumarathasan P, Blais E, Saravanamuthu A, Bielecki A, Mukherjee B, Bjarnason S, et al. Nitrative stress, oxidative stress and plasma endothelin levels after inhalation of particulate matter and ozone. Part. Fibre Toxicol. 2015;12:28.

12. Martin R, Dowling K, Pearce D, Sillitoe J, Florentine S. Health effects associated with inhalation of airborne arsenic arising from mining operations. Geosciences. 2014;4:128-75.

13. Smith JRH, Etherington G, Shutt AL, Youngman MJA. Study of aerosol deposition and clearance from the human nasal passage. Ann Occup Hyg 2002;46:309-13.

14. Asgharian B, Hofmann W, Miller FJ. Mucociliary clearance of insoluble particles from the tracheobronchial airways of the human lung. J Aerosol Sci. 2001;32:817-32.

15. Smith JRH, Bailey MR, Etherington G, Shutt AL, Youngman MJ. Effect of particle size on slow particle clearance from the bronchial tree. Exp Lung Res. 2008;34:287-312.

16. Labiris NR, Dolovich MB. Pulmonary drug delivery. Part I: physiological factors affecting therapeutic effectiveness of aerosolized medications. $\mathrm{Br}$ J Clin Pharmacol. 2003;56:588-99.

17. Alleman LY, Lamaison L, Perdrix E, Robache A, Galloo J-C. PM10 metal concentrations and source identification using positive matrix factorization and wind sectoring in a French industrial zone. Atmospheric Res. 2010;96:612-25.

18. Mbengue S, Alleman LY, Flament P. Size-distributed metallic elements in submicronic and ultrafine atmospheric particles from urban and industrial areas in northern France. Atmospheric Res. 2014;135-136:35-47.

19. Hamel SC, Buckley B, Lioy PJ. Bioaccessibility of metals in soils for different liquid to solid ratios in synthetic gastric fluid. Environ. Sci. Technol. 1998;32:358-62.

20. Yang A, Jedynska A, Hellack B, Kooter I, Hoek G, Brunekreef B, et al. Measurement of the oxidative potential of PM 2.5 and its constituents: the effect of extraction solvent and filter type. Atmos Environ. 2014;83:35-42.

21. Jacobo-Estrada T, Cardenas-Gonzalez M, Santoyo-Sánchez M, Parada-Cruz B, Uria-Galicia E, Arreola-Mendoza L, et al. Evaluation of kidney injury biomarkers in rat amniotic fluid after gestational exposure to cadmium. J Appl Toxicol JAT. 2016;36:1183-93.

22. Knaapen AM, Shi T, Borm PJA, Schins RPF. Soluble metals as well as the insoluble particle fraction are involved in cellular DNA damage induced by particulate matter. Mol Cell Biochem. 2002;234-235:317-26.

23. Wegesser TC, Last JA. Lung response to coarse PM: bioassay in mice. Toxicol Appl Pharmacol. 2008:230:159-66.

24. Livak KJ, Schmittgen TD. Analysis of relative gene expression data using real-time quantitative $P C R$ and the $2-\Delta \Delta C T$ method. Methods. 2001:25:402-8.

25. McLennan SM. Relationships between the trace element composition of sedimentary rocks and upper continental crust. Geochem Geophys Geosystems. 2001;2:1021.

26. Tsai M-Y, Hoek G, Eeftens M, de Hoogh K, Beelen R, Beregszászi T, et al. Spatial variation of PM elemental composition between and within 20 European study areas — results of the ESCAPE project. Environ Int. 2015;84:181-92.

27. Sterckeman T, Douay F, Proix N, Fourrier H. Vertical distribution of $\mathrm{cd}, \mathrm{Pb}$ and $\mathrm{Zn}$ in soils near smelters in the north of France. Environ Pollut. 2000;107:377-89.

28. Batonneau Y, Bremard C, Gengembre L, Laureyns J, Le Maguer A, Le Maguer D, et al. Speciation of PM10 sources of airborne nonferrous metals within the 3-km zone of lead/zinc smelters. Environ. Sci. Technol. 2004:38:5281-9.

29. Sobanska S, Ricq N, Laboudigue A, Guillermo R, Brémard C, Laureyns J, et al. Microchemical investigations of dust emitted by a lead smelter. Environ Sci Technol. 1999;33:1334-9.

30. Pakkanen TA, Loukkola K, Korhonen $\mathrm{CH}$, Aurela M, Mäkelä T, Hillamo RE, et al. Sources and chemical composition of atmospheric fine and coarse particles in the Helsinki area. Atmos Environ. 2001;35:5381-91.

31. Maenhaut W, Raes N, Chi X, Cafmeyer J, Wang W, Salma I. Chemical composition and mass closure for fine and coarse aerosols at a kerbside in Budapest, Hungary, in spring 2002. X-Ray Spectrom. 2005;34:290-6.

32. Méndez LB, Gookin G, Phalen RF. Inhaled aerosol particle dosimetry in mice: a review. Inhal Toxicol. 2010;22:1032-7.
33. Blesa S, Cortijo J, Mata M, Serrano A, Closa D, Santangelo F, et al. Oral $\mathrm{N}$-acetylcysteine attenuates the rat pulmonary inflammatory response to antigen. Eur Respir J. 2003;21:394-400.

34. Pichavant $\mathrm{M}$, Rémy $\mathrm{G}$, Bekaert $\mathrm{S}$, Le Rouzic $\mathrm{O}$, Kervoaze $\mathrm{G}$, Vilain $\mathrm{E}$, et al. Oxidative stress-mediated iNKT-cell activation is involved in COPD pathogenesis. Mucosal Immunol. 2014;7:568-78.

35. Charrier JG, MCFall AS, Richards-Henderson NK, Anastasio C. Hydrogen peroxide formation in a surrogate lung fluid by transition metals and quinones present in particulate matter. Environ. Sci. Technol. 2014;48: 7010-7.

36. Huang $\mathrm{S}, \mathrm{Hu} H$, Sánchez BN, Peterson KE, Ettinger AS, Lamadrid-Figueroa $H$, et al. Childhood blood lead levels and symptoms of attention deficit hyperactivity disorder (ADHD): a cross-sectional study of Mexican children. Environ Health Perspect. 2016;124:868-74.

37. Liao LM, Friesen MC, Xiang Y-B, Cai H, Koh D-H, Ji B-T, et al. Occupational lead exposure and associations with selected cancers: the shanghai Men's and Women's health study cohorts. Environ Health Perspect. 2016;124:97-103.

38. Querol X, Viana M, Alastuey A, Amato F, Moreno T, Castillo S, et al. Source origin of trace elements in PM from regional background, urban and industrial sites of Spain. Atmos Environ. 2007:41:7219-31.

39. Wiseman CLS, Zereini F. Characterizing metal(loid) solubility in airborne PM10, PM2.5 and PM1 in Frankfurt, Germany using simulated lung fluids. Atmos Environ. 2014;89:282-9.

40. Stayner L, Smith R, Thun M, Schnorr T, Lemen RA. Dose-response analysis and quantitative assessment of lung cancer risk and occupational cadmium exposure. Ann Epidemiol. 1992;2:177-94.

41. Dervan PA, Hayes JA. Peribronchiolar fibrosis following acute experimental lung damage by cadmium aerosol. J Pathol. 1979;128:143-9.

42. Breton J, Daniel C, Vignal C, Body-Malapel M, Garat A, Plé C, et al. Does oral exposure to cadmium and lead mediate susceptibility to colitis? The darkand-bright sides of heavy metals in gut ecology. Sci Rep. 2016;6:19200.

43. Celik I, Gallicchio L, Boyd K, Lam TK, Matanoski G, Tao X, et al. Arsenic in drinking water and lung cancer: a systematic review. Environ Res. 2008;108:48-55.

44. Lu K, Abo RP, Schlieper KA, Graffam ME, Levine S, Wishnok JS, et al. Arsenic exposure perturbs the gut microbiome and its metabolic profile in mice: an integrated metagenomics and metabolomics analysis. Environ Health Perspect. 2014;122:284-91.

45. Monn C, Becker S. Cytotoxicity and induction of Proinflammatory cytokines from human monocytes exposed to fine (PM2.5) and coarse particles (PM10-2.5) in outdoor and indoor air. Toxicol Appl Pharmacol. 1999;155:245-52

46. Bollati V, Marinelli B, Apostoli P, Bonzini M, Nordio F, Hoxha M, et al. Exposure to metal-rich particulate matter modifies the expression of candidate MicroRNAs in peripheral blood leukocytes. Environ Health Perspect. 2010;118:763.

47. Williams AE, Perry MM, Moschos SA, Larner-Svensson HM, Lindsay MA. Role of miRNA-146a in the regulation of the innate immune response and cancer. Biochem Soc Trans. 2008;36:1211-5.

48. Ghorpade DS, Sinha AY, Holla S, Singh V, Balaji KN. NOD2-Nitric Oxideresponsive MicroRNA-146a Activates Sonic Hedgehog Signaling to Orchestrate Inflammatory Responses in Murine Model of Inflammatory Bowel Disease. J Biol Chem. 2013:288:33037-48.

49. World Health Organization. WHO | Exposure to ambient air pollution [Internet]. WHO. 2016 [cited 2016 Dec 29]. Available from: http://www.who. int/gho/phe/outdoor_air_pollution/exposure/en/

50. Brook RD, Franklin B, Cascio W, Hong Y, Howard G, Lipsett M, et al. Air pollution and cardiovascular disease a statement for healthcare professionals from the expert panel on population and prevention science of the American Heart Association. Circulation. 2004;109:2655-71.

51. Charron A, Harrison RM. Fine (PM2.5) and coarse (PM2.5-10) particulate matter on a heavily trafficked London highway: sources and processes. Environ. Sci. Technol. 2005;39:7768-76.

52. Gurjar BR, Ravindra K, Nagpure AS. Air pollution trends over Indian megacities and their local-to-global implications. Atmos Environ. 2016; 142:475-95

53. Huang K, Zhuang G, Lin Y, Wang Q, JS F, Fu Q, et al. How to improve the air quality over megacities in China: pollution characterization and source analysis in shanghai before, during, and after the 2010 world expo. Atmospheric. Chem Phys. 2013;13:5927-42.

54. Schins RPF, Lightbody JH, Borm PJA, Shi T, Donaldson K, Stone V. Inflammatory effects of coarse and fine particulate matter in relation to chemical and biological constituents. Toxicol Appl Pharmacol. 2004;195:1-11. 
55. Cho S-H, Tong H, McGee JK, Baldauf RW, Krantz QT, Gilmour MI. Comparative toxicity of size-fractionated airborne particulate matter collected at different distances from an urban highway. Environ Health Perspect. 2009;117:1682-9.

56. Wegesser TC, Last JA. Mouse lung inflammation after instillation of particulate matter collected from a working dairy barn. Toxicol Appl Pharmacol. 2009:236:348

57. Farina F, Sancini G, Mantecca P, Gallinotti D, Camatini M, Palestini P. The acute toxic effects of particulate matter in mouse lung are related to size and season of collection. Toxicol Lett. 2011;202:209-17.

58. Saravia J, You D, Thevenot P, Lee Gl, Shrestha B, Lomnicki S, et al. Early-life exposure to combustion-derived particulate matter causes pulmonary immunosuppression. Mucosal Immunol. 2014;7:694-704.

59. Breznan D, Karthikeyan S, Phaneuf M, Kumarathasan P, Cakmak S, Denison MS, et al. Development of an integrated approach for comparison of in vitro and in vivo responses to particulate matter. Part Fibre Toxicol. 2016:13:41.

60. van Voorhis M, Knopp S, Julliard W, Fechner JH, Zhang X, Schauer JJ, et al. Exposure to atmospheric particulate matter enhances Th17 polarization through the aryl hydrocarbon receptor. PLoS One. 2013;8:e82545.

61. Pichavant M, Goya S, Meyer EH, Johnston RA, Kim HY, Matangkasombut P, et al. Ozone exposure in a mouse model induces airway hyperreactivity that requires the presence of natural killer T cells and IL-17. J Exp Med. 2008;205:385-93.

62. Montbarbon M, Pichavant M, Langlois A, Erdual E, Maggiotto F, Neut C, et al. Colonic inflammation in mice is improved by cigarette smoke through iNKT cells recruitment. PLoS One. 2013;8:e62208.

63. Kish L, Hotte N, Kaplan GG, Vincent R, Tso R, Gänzle M, et al. Environmental particulate matter induces murine intestinal inflammatory responses and alters the gut microbiome. PLoS One. 2013:8:e62220.

64. Salim SY, Kaplan GG, Madsen KL. Air pollution effects on the gut microbiota: a link between exposure and inflammatory disease. Gut Microbes. 2014;5:215-9.

65. Sinagra E, Pompei G, Tomasello G, Cappello F, Morreale GC, Amvrosiadis G, et al. Inflammation in irritable bowel syndrome: myth or new treatment target? World J Gastroenterol. 2016;22:2242.

66. Morris G, Berk M, Carvalho AF, Caso JR, Sanz Y, Maes M. The role of microbiota and intestinal permeability in the pathophysiology of autoimmune and Neuroimmune processes with an emphasis on inflammatory bowel disease type 1 diabetes and chronic fatigue syndrome. Curr Pharm Des. 2016;22:6058-75.

67. Viennois E, Merlin D, Gewirtz AT, Chassaing B. Dietary emulsifier-induced low-grade inflammation promotes colon carcinogenesis. Cancer res. 2016:canres1359.2016.

68. Winer DA, Luck H, Tsai S, Winer S. The intestinal immune system in obesity and insulin resistance. Cell Metab. 2016;23:413-26.

69. Chassaing B, Gewirtz AT. Gut microbiota, low-grade inflammation, and metabolic syndrome. Toxicol Pathol. 2014;42:49-53.

70. Severance GE, Tveiten DH, Lindström LH, Yolken RL, Reichelt K. The gut microbiota and the emergence of autoimmunity: relevance to major psychiatric disorders. Curr Pharm Des. 2016;22:6076-86.

71. Xin X, Dai W, Wu J, Fang L, Zhao M, Zhang P, et al. Mechanism of intestinal mucosal barrier dysfunction in a rat model of chronic obstructive pulmonary disease: an observational study. Exp. Ther. Med. 2016;12:1331-6.

72. Pardo M, Porat Z, Rudich A, Schauer JJ, Rudich Y. Repeated exposures to roadside particulate matter extracts suppresses pulmonary defense mechanisms. Resulting in lipid and protein oxidative damage. Environ. Pollut. Barking Essex 1987. 2015;210:227-37.

73. Shang Y, Zhang L, Jiang Y, Li Y, Airborne LP. Quinones induce cytotoxicity and DNA damage in human lung epithelial A549 cells: the role of reactive oxygen species. Chemosphere. 2014;100:42-9.

74. Lu S, Li Y, Zhang J, Zhang T, Liu G, Huang M, et al. Associations between polycyclic aromatic hydrocarbon (PAH) exposure and oxidative stress in people living near e-waste recycling facilities in China. Environ Int. 2016;94:161-9.

75. Dianat M, Radmanesh E, Badavi M, Goudarzi G, Mard SA. The effects of PM10 on electrocardiogram parameters, blood pressure and oxidative stress in healthy rats: the protective effects of vanillic acid. Environ Sci Pollut Res. 2016;23:19551-60

76. Bertazzi PA, Cantone L, Pignatelli P, Angelici L, Bollati V, Bonzini M, et al. Does enhancement of oxidative stress markers mediate health effects of ambient air particles? Antioxid Redox Signal. 2013;21:46-51.

77. Samuni Y, Goldstein S, Dean OM, Berk M. The chemistry and biological activities of N-acetylcysteine. Biochim Biophys Acta. 2013;1830:4117-29.

78. Jin HM, Zhou DC, HF G, Qiao QY, SK F, Liu XL, et al. Antioxidant Nacetylcysteine protects pancreatic $\beta$-cells against aldosterone-induced oxidative stress and apoptosis in female $\mathrm{db} / \mathrm{db}$ mice and insulin-producing MIN6 cells. Endocrinology. 2013;154:4068-77.

79. Lin H, Liu X, Yu J, Hua F, Antioxidant HZ. N-acetylcysteine attenuates hepatocarcinogenesis by inhibiting ROS/ER stress in TLR2 deficient mouse. PLoS One. 2013;8:e74130.

80. Amrouche-Mekkioui I, Djerdjouri BN. Acetylcysteine improves redox status, mitochondrial dysfunction, mucin-depleted crypts and epithelial hyperplasia in dextran sulfate sodium-induced oxidative colitis in mice. Eur J Pharmacol. 2012:691:209-17.

81. Ebrahimi F, Esmaily H, Baeeri M, Mohammadirad A, Fallah S, Abdollahi M. Molecular evidences on the benefit of $\mathrm{N}$-acetylcysteine in experimental colitis. Open. Life Sci. 2008:3:135-42.

82. Lorber A, Baumgartner WA, Bovy RA, Chang CC, Hollcraft R. Clinical application for heavy metal-complexing potential of $\mathrm{N}$-acetylcysteine. J Clin Pharmacol. 1973:13:332-6.

83. Banner W, Koch M, Capin DM, Hopf SB, Chang S, Tong TG. Experimental chelation therapy in chromium, lead, and boron intoxication with $\mathrm{N}$ acetylcysteine and other compounds. Toxicol Appl Pharmacol. 1986;83:142-7.

84. Ercal N, Treeratphan P, Hammond TC, Matthews RH, Grannemann NH, Spitz DR. Vivo indices of oxidative stress in lead-exposed C57BL/6 mice are reduced by treatment with meso-2,3-Dimercaptosuccinic acid or Nacetylcysteine. Free Radic Biol Med. 1996;21:157-61.

85. Flora SJ. Arsenic-induced oxidative stress and its reversibility following combined administration of $\mathrm{N}$-acetylcysteine and meso 2,3dimercaptosuccinic acid in rats. Clin Exp Pharmacol Physiol. 1999;26:865-9.

86. Tulic MK, Vivinus-Nébot M, Rekima A, Medeiros SR, Bonnart C, Shi H, et al. Presence of commensal house dust mite allergen in human gastrointestinal tract: a potential contributor to intestinal barrier dysfunction. Gut. 2016;65:757-66.

87. Trompette A, Gollwitzer ES, Yadava K, Sichelstiel AK, Sprenger N, Ngom-Bru C, et al. Gut microbiota metabolism of dietary fiber influences allergic airway disease and hematopoiesis. Nat Med. 2014;20:159-66.

88. Wang J, Li F, Wei H, Lian Z-X, Sun R, Tian Z. Respiratory influenza virus infection induces intestinal immune injury via microbiota-mediated Th17 cell-dependent inflammation. J Exp Med. 2014;211:2397-410.

89. Schuijt TJ, Lankelma JM, Scicluna BP, de Sousa E, Melo F, Roelofs JJTH, de Boer JD, et al. The gut microbiota plays a protective role in the host defence against pneumococcal pneumonia. Gut. 2016;65(4):575-83.

90. Allais L, Kerckhof F-M, Verschuere S, Bracke KR, De Smet R, Laukens D, et al. Chronic cigarette smoke exposure induces microbial and inflammatory shifts and mucin changes in the murine gut. Environ Microbiol. 2016;18:1352-63.

91. Zuo L, Li Y, Wang H, Wu R, Zhu W, Zhang W, et al. Cigarette smoking is associated with intestinal barrier dysfunction in the small intestine but not in the large intestine of mice. J Crohns Colitis. 2014;8:1710-22.

\section{Submit your next manuscript to BioMed Central and we will help you at every step:}

- We accept pre-submission inquiries

- Our selector tool helps you to find the most relevant journal

- We provide round the clock customer support

- Convenient online submission

- Thorough peer review

- Inclusion in PubMed and all major indexing services

- Maximum visibility for your research

Submit your manuscript at www.biomedcentral.com/submit
Biomed Central 